\title{
Environmental Protection of Port Logistics Using Phase Analysis
}

\author{
Jaromir Mares ${ }^{1 *}$, Aly Hawa Camara ${ }^{1}$, Ghiţă Bârsan², Dănuţ Moşteanu² \\ ${ }^{1}$ University of Defence, Faculty of Military Leadership, Department of Logistics, Brno, Czech Republic \\ ${ }^{2}$ Academy of Land Forces Nicolae Bălcescu, Sibiu, Romania
}

Received: 14 May 2018

Accepted: 8 October 2018

\begin{abstract}
The paper explores port logistics of the Republic of Guinea with a focus on environmental protection. The aim of the article is to point out the risks resulting from the development of port infrastructure in parts where daily operations are in place. Two comparison methods were used on soil samples: X-ray diffraction and optical-electronic microscopy based on the harmfulness of each analyzed sample. The leaching tests were connected with thermodynamic modelling in order to determine the element speciation and the saturation indices of possibly precipitating solid phases. The results of thermodynamic models were supplemented by the determination of newly formed phases, using X-ray diffraction phase analysis. The PHREEQC-2 model was used for simulations of arsenic and other elements at the surface of hydrous ferric oxides. The leaching tests revealed that in organic complexes and in extremely basic solutions, high amounts of $\mathrm{Pb}$ and other toxic elements are released. It has been confirmed that a suitable alternative to determine the volume of sulphur over $50 \mathrm{mg} / \mathrm{kg}$ in geomaterials is the combustion method with infrared detection.
\end{abstract}

Keywords: contamination scope port infrastructure, diffraction analysis, leaching test, PHREEQC-2 model, thermodynamic model

\section{Introduction}

Environmental protection is a present global issue. In terms of port logistics, it includes all transport on water, activities in wharves and all material and burden handling on roads in the port. It is clear that all services and activities relate to compliance with ecological measures.

In particular, this concerns traffic on water, traffic along port roads, repairs and maintenance and connected manufacturing plants. Not far from many ports is the

*e-mail: jaromir.mares@unob.cz, jarmes@seznam.cz production of fuels and lubricants from imported crude oil, which takes place together with other chemical production and processes.

These activities directly represent risks and threats to the environment. In recent years, environmental protection has been considered as an investment in the future and as a significant competitive advantage. The attitude of companies toward this issue is changing, resulting in cooperation between environmental organizations and business enterprises. This directly connects the efforts to transfer from subsequent technological solutions of environmental problems. The best possible utilization of the life cycle of a product is sought after, from the input of materials and energy 
through manufacturing and use and up to the final disposal of the product. The number of companies that are run in a sustainable way and institutions selecting a creative and proactive stance to environmental protection has been rising year by year as younger and more sustainable-oriented managers are emerging [1], which is positive for both environmental protection and the health and safety of the personnel.

The contribution is focused on the logistics of the Economic Community of West African States, also known as ECOWAS. This fits within the framework of spatial changes that are a major problem for all nations of the world. Many nations face demographic and economic changes [2]. Modern commercial ports especially face naval gigantism - port development relating to the geographic location, storage facilities and equipment, the readiness to perform various phases of handling and port organization. The adaptation of the ports of the Republic of Guinea leading to organizational changes is a major socio-economic problem [3] because their central location is not favorable due to the importance of flows that make up the competitiveness of the transportation chain.

In the conceptual development, it is important how logistics contributes to port performance and how it improves economic flow management. Using the analysis done enables coping with the problems of how to improve information management in ports and their overall performance. The research has been carried out within a project focused on several areas in Guinean ports and can contribute to the improvement of the information system for the realization of the necessary communication network and information flow [4].

The aim of the research is to optimize the performance of port logistics in the Republic of Guinea. At the same time, it is a contribution to ongoing efforts to achieve better understanding of the measures to be taken for strengthening the country and the ECOWAS zone. The consequences of port pollution affect the environment, do not respect national boundaries and, therefore, there is an environmental issue under strong international pressure.

\section{Current Stage in Research Problems}

The quality of the environment from the viewpoint of port logistics in international ports is significant. It is necessary to contribute to the health and safety concerning a military or a civilian port.

The presence of hazardous wastes prevents the development of port logistics. In the Republic of Guinea, they also include especially fly ash from flue gas cleaning of high-temperature metallurgical plants. Interest in and the study of the characterization of waste products is growing $[5,6]$.

In addition to the detailed chemical and mineralogical description of fly ashes, the purpose of examining the environmental risks is to carry out a number of experiments in the form of leaching tests. The studied area (the object of exploration) was the vicinity of metallurgical works in Kankan, which is connected to the environmental protection related to port logistics. With regard to the danger of soil and water contamination, African countries are an important research location, a natural laboratory, which is currently studied by a number of authors [7-10].

The Republic of Guinea is located by the Atlantic Ocean. Port logistics represent one of its major and most important transport industries. This connects the shipping in the synchronization with other modes of transport (air, land). The quality of the environment is important from the viewpoint of logistics in international ports. It is reasonably necessary to contribute to the healthy and safe operation of both its civilian and military parts [11-13].

The biggest environmental problem from the logistics viewpoint is air pollution caused by emissions from transport, waste management and hazards arising from floods as well as from industrial and metallurgical wastes [14-17]. Slag, metallurgical slag and especially glazed materials are investigated intensively since they contain a high proportion of heavy metals and other toxic substances. The guidelines of the international community define slag and metallurgical slag as hazardous materials [18-20].

Currently, the strategy for processing, storing and using wastes is a burning topic, addressed in many specialized papers from different perspectives of the type of waste, of the source of waste and the solutions for proper waste management [21-23]. This is also the case of the Republic of Guinea, where waste management is the subject of passionate debates in view of the harmonization of the legal regulations of the African Community. For several decades, many places throughout the Republic of Guinea have been exposed to considerable environmental pollution. Since 1982, groundwater pollution and soil pollution have increased, especially in the vicinity of factories, companies and other major sources of pollution. New technologies have sometimes been used to reduce environmental pollution $[24,25]$.

A large volume of landfill wastes is a potential source of environmental pollution [26]. The capture of emissions from solid waste disposal sites is a priority [27]. Mechanical separators are primarily based on the separation of solid particles according to different gas and particle densities through the process of gravity or inertia [28]. The methods of elemental analysis help define the chemical composition of fly ash. They can be divided into two basic groups. The methods of the first group work with solid samples (e.g. X-ray fluorescence analysis /XRF, instrumental neutron activation analysis/ INAA, raman spectroscopy/RS and electron probe microanalysis/EPMA) [29, 30].

The second major group of chemical-analytical methods currently used work with the samples in the 
form of a solution. (AAS, ICP OES, ICP MS) [31-33]. Therefore, solid samples require preliminary treatment, i.e., decomposition. The advantage of the liquid sample is primarily its homogeneity and the possibility of dosing smaller amounts during the analysis [34, 35].

Within port logistics, it is a very diverse area. Globalization has not led to the integration of the labor market, energy or trade, and to the preservation and strengthening of local identities [36, 37]. Port logistics is all the activity associated with port operations, whether they are passenger or freight parts of ports. Coping with the logistics impacts on the environment is related to their identification and an attempt at explanation. With the globalization of the economy, by 1980 transport was often considered to be a sector of unlimited growth, connected with an increase in mobility. The situation has changed with the awareness of environmental impacts in the transport sector. The ever-increasing demand for transport can damage the economy compared with productivity (e.g., congestion) and cause pollution.

The transport geography of the Economic Community of West African States is explained by the main factors that analyze the situation. They concern the acceleration of spatial change in shipping logistics and the ports of the Republic of Guinea. They show the importance in the economic, environmental and political spheres. Port logistics has become one of the sectors, crucial in different fields, especially in geography, in terms of functioning.

A detailed characterization of the waste is a necessary component to estimate its impact on the environment. The long-term global research of the waste in the surface wastelands have been a topic of many studies in the field of the environment. Slag, metallurgical slag and other materials are studied intensively because they contain high amounts of heavy metals and other toxic substances. The Guidelines of the United Nations define slag and metallurgical slag as dangerous substances. On the other hand, the same substances are considered to be commercial materials and are, therefore, used as an aggregate in the road building in some countries [38, 39].

The degree of the soil pollution seems to be directly connected to mineralogy of the emissions of the primary particles. Some studies [40] and [41] have focused on primary lead dust and its emissions, from which it follows that chemistry and mineralogy of the emission can be very complicated, especially in the combination of water-air. Dangerous wastes are produced, for example during primary lead smelting when processing $\mathrm{Pb}-\mathrm{Ag}-\mathrm{Zn}$ from ores [40]. On the contrary, the residues of secondary lead smelting and scrap processing (especially car batteries) consist of lead chlorides (caracolite $\mathrm{Na}_{3} \mathrm{~Pb}_{2}\left(\mathrm{SO}_{4}\right)_{3} \mathrm{Cl}$, potassium chloride $\mathrm{KCl} \cdot \mathrm{PbCl}_{2}$, cotunnite $\mathrm{PbCl}_{2}$, and laurionite $\mathrm{Pb}(\mathrm{OH}) \mathrm{Cl})$. These chlorides are usually more soluble than sulphides and sulphates [42]. Up to now, not many studies investigating infusion of the residues from the basic metals in steelworks have been published [43, 44].
The presented paper is an output of the tests on the samples consisting of the residues of the lead melting. During their wash up near ports the environment can be easily damaged. The experiment was suggested as a test for a change of the composition of the solutions to determine preferential dissolution in various phases. This was performed only with the tests valid for one year. Such types of samples were selected considering the differences in the mineralogical composition.

The aim of the article presented is to provide an answer to a question relating to the composition of the wastes and determine their harmful effects, and to point out the risk of not dealing with the existing situation.

\section{Methods and Material}

\section{Quantitative X-ray Diffraction Analysis}

Quantitative X-ray diffraction analysis is one of the most important applications of X-ray diffraction techniques. To determine a phase composition of the substance (qualitative analysis), X-ray diffraction utilizes X-ray beams targeted to hit crystallized matter and generate a diffraction pattern. The determination of the phase composition can therefore be processed based on the comparison of the diffractogram of an analyzed substance with a reference file containing diffractograms of the known substances. These are gathered in databases as, for example, ICDD PDF (international centre for diffraction data, powder diffraction file). In the mixture of substances, each component creates a diffraction pattern independently of the others, so a diffractogram of the mixture is a superposition of diffractograms that would have been gained from each of the components on its own. The technique can also be used for the qualitative analysis of the mixture to identify all substances that are present. [45, 46].

The methodology of establishing the volume of each phase derives from the way of measuring the extensive quantity of state. Magnetometric methods originate from measuring the magnetic moment, dilatometry methods from the measured volume, and microscopic methods from the breakdown of numeric characteristics of statistical sets describing linear proportions of monophasic areas in this or that way. It has several advantages against the element analysis. It determines directly each crystalline phase. Further, the analyzed sample will not be damaged during quantitative X-ray diffraction analysis and it is still available for further tests.

X-ray diffraction analysis requires only a small amount of the substance. Apart from the advantages of common analytical methods, X-ray diffraction analysis has certain disadvantages. It is restricted to substances in the form of crystals and the achieved accuracy, and the limit of detectability are substantially worse than in element analysis [47-49]. In the methods of quantitative phase analysis, which are based on the comparison of 
the intensity rate of diffraction lines of the examined phase and the intensity of reference material, we use the so-called corundum number, labelled as abbreviation RIR (reference intensity ratio).

As a suitable reference material due to its high chemical stability, the absence of impacts caused by preferential orientation and availability in the powder form corundum $\mathrm{Al}_{2} \mathrm{O}_{3}$ was chosen. RIR (also IIc) is defined as a ratio of the strongest peak of researched phase to the strongest peak of corundum in a mixture created in mass proportion 1:1. This ratio is equal to the ratio of the calibration constants $\mathrm{K}_{\mathrm{sj}}$ and $\mathrm{K}_{\mathrm{hc}}$ :

$$
(R I R)_{j}=\frac{I_{s j}}{I_{h c}}=\frac{K_{s j}}{K_{h c}}=\beta_{j c^{\prime}}
$$

...where index $c$ is the reference of corundum and indices $s$ and $h$ are the strongest peak phases of $j$ and corundum. The values of RIR are defined for $\mathrm{CuK}_{\text {a }}$ radiation for Bragg-Brentano focus reflex geometry with a constant deviation of the aperture.

If a different kind of radiation or a different way of geometric layout of diffractometer is used, it is necessary to perform a mathematical correction. There are three known basic techniques for determining RIR:

Measuring of a powder mixture of the clear phase and counting RIR

Measuring of a powder mixture - the ratio of 1:1 of the mixture of corundum and used in the analysis is the strongest peak for corundum and analytic $j$. Then RIR is defined by a quotation (2). If the weight ratio in the mixture is not 1:1, the pair of peaks and weigh fraction or if the pairs of the strongest peaks are not chosen, then for them the expression of RIR in the following equation is valid:

$$
(R I R)_{j}=\frac{c_{c}}{c_{j}} \frac{a_{k c}}{a} \frac{I_{i j}}{I_{k c}}
$$

...where $c_{c}$ and $c_{j}$ are weight fractions of corundum and analyte $j$ in the mixture; $\mathrm{I}_{\mathrm{ij}}$ and $\mathrm{I}_{\mathrm{kc}}$ are intensities of observed chosen pairs of peaks and $\mathrm{a}_{\mathrm{kc}}$; and $\mathrm{a}_{\mathrm{ij}}$ are relative intensities of the same peaks.

Measuring of the clear phase - from the measured clear phases RIR can be determined from the equation:

$$
(R I R)=\frac{K_{s j}}{K_{h c}} \frac{\left(I_{s j}\right)_{0}}{\left(I_{h c}\right)_{0}} \frac{\mu_{j}}{\mu_{c}}
$$

...where $\left(\mathrm{I}_{\mathrm{sj}}\right) 0$ and $\left(\mathrm{I}_{\mathrm{hc}}\right) 0$ are intensities of the strongest peaks of phase $j$ and corundum in the corresponding clear phase; $\mu_{\mathrm{i}}$ and $\mu_{\mathrm{c}}$ are weight absorption coefficients of the clear phase and corundum. The parallel resolution of RIR in the mixture and clear phase is identified and statistically considerably different.

Counting RIR - as mentioned previously, the values of RIR are defined for $\mathrm{CuK}_{\alpha}$ radiation. The structural factor is not dependent on the radiation used because the atomic dispersion factor is dependent only on . From equation (3) it is possible to derive:

$$
I_{i j}=\left[\frac{r_{0}^{2}}{32 \pi}\right]\left[\frac{I_{0} B H_{c} \lambda^{3}}{R}\right]\left[\frac{1+\cos ^{2} 2 \theta_{i}}{\sin ^{2} \theta_{i} \cos \theta_{i}}\right]\left[\frac{\left|F_{i j}\right|^{2} D_{i j} M_{i j}}{\vartheta_{j}^{2}}\right]\left[\frac{v_{j}}{2 \mu}\right]
$$

... and can be (RIR), for the wavelength $\lambda$ defined by equation:

$$
(R I R)_{\lambda}=R I R\left(\frac{(L P)_{\lambda}}{L P}\right)_{j}\left(\frac{L P}{(L P)_{\lambda}}\right)_{c}\left(\frac{\mu_{\lambda}}{\mu}\right)_{j}\left(\frac{\mu}{\mu_{\lambda}}\right)_{c}
$$

...where RIR is a ration of reference intensity defined for $\mathrm{CuK}_{\alpha}$ radiation, LP is the so-called Lorentz-polarization factor, index $\lambda$ is wavelength and indices $j$ and symbolize phases $j$ and corundum. If we consider that the absorption coefficient in reference material $k$ is competing with the absorption coefficient of phase $j$, then for the strongest measured peaks $k$ and $j$. They are in the mixture in ratio 1:1 and equation for a coefficient applies:

$$
\beta_{j k}=\frac{I_{s j}}{I_{h k}}
$$

...which is not affected by micro absorption, where $s$ and $\mathrm{k}$ are the strongest peaks and after that it is possible to write equation (7):

$$
(\mathrm{RIR})_{j}=\beta j k(\mathrm{RIR})_{k} \text {, }
$$

...where (RIR) $)_{\mathrm{k}}$ is certified for intensity of standard $k$. Method RIR was applied for the first time by Wolff and Visser, where as inner standard they used corundum [43].

\section{Subject of the Research}

The soil samples collected in the Republic of Guinea with clear spot collection identification were a subject of the research. The samples were collected around ports. The experiment was suggested as a test for a change in the composition of the solutions to determine preferential dissolution in various phases. This was performed only with the tests valid for one year. Such types of samples were selected considering the differences in the mineralogical composition.

The samples collected weighed $3 \mathrm{~kg}$. Each of the samples was stored in a see-through plastic bag and was subject to laboratory analysis. The samples were investigated as a part of the project on environmental protection in developing countries with the aim to protect the environment and the environmental conditions of the port personnel during the fulfilment of the usual daily tasks of port logistics. Two types of experimental evaluation ranking were used. Namely 
the Czech standard EU/CZ (European norm, further only referred to as I) [50] and the American standard (US EPA, further only as II) symbolised by TCLP [51]. Samples $\mathrm{C}$ and $\mathrm{D}$ were analyzed by mass spectrometer.

\section{Measuring Appliances Used}

For the actual measuring we used appliances and devices for experimental measuring, namely a diffractometer AXS Bruker D8 Discover with the cobalt X-ray lamp $\left(\lambda \mathrm{K}_{\alpha}=0,179021 \mathrm{~nm}\right)$ located in the Research Centre of Nanotechnology, University Gamal Abdel Nasser. Mounted to this diffractometer was a large area, by gas-filled proportional detector, which is a foundation of the system GADDS. The measuring apparatus provided several advantages, one of which was immediate saving of the recorded data to a memory device. Physical-chemical parameters such as the $\mathrm{pH}$ and conductivity were determined in both solutions.

The second experiment was done in a laboratory using the European standard (and the Czech norm). BATCH (one test performed on several samples) was used in reactors HDPE of the volume of $200 \mathrm{ml}$ nitric acid $\left(\mathrm{HNO}_{3}\right)$. In each reactor a solid phase was marked and its ratio with the fluid was 10:1. The experiment ran for $24 \pm 0.5$ hours.

All samples were analyzed with the help of X-ray diffraction, optical and electronic microscopy. Using the stated methods, chemical and mineralogical composition of the samples was determined. The ICP-MS mass spectrometer was used for trace analysis of the assessed elements.

\section{Results and Discussion}

The overview of the chemical elements of two samples is stated in Table 1. Marking I means the analysis performed by the method under the norm EU/CZ and marking II is the analysis performed according to the norm U.S. EPA.

The main chemical components are $\mathrm{Pb}, \mathrm{Cl}, \mathrm{Na}$ and $\mathrm{K}$. In comparison with sample B, sample A is enriched with more $\mathrm{Pb}, \mathrm{K}$ and $\mathrm{Cd}$, by contrast to sample $\mathrm{B}$, which is richer in $\mathrm{Na}$, As and $\mathrm{Sb}$. The enrichment of sample $\mathrm{B}$ on $\mathrm{Na}$ and $\mathrm{S}_{\text {tot }}$ closely relates to the X-ray results, which show the presence of nardite $\left(\mathrm{Na}_{2} \mathrm{SO}_{4}\right)$ (Fig. 1).

Table 1. List of chemical element samples $(\mathrm{mg} / \mathrm{kg})$.

\begin{tabular}{|c|c|c|c|c|c|c|}
\hline Sample No & $14 / 1$ & $14 / 2$ & $14 / 3$ & $14 / 4$ & $14 / 5$ & $14 / 6$ \\
\hline Sample and method & A-I & A-II & B-I & B-II & C & D \\
\hline $\mathrm{Fe}^{2+}$ & 4830 & 5190 & 3985 & 3520 & 34085 & 74900 \\
\hline $\mathrm{Mn}^{2+}$ & 174 & 175 & 76 & 77 & 415 & 119 \\
\hline $\mathrm{Mg}^{2+}$ & 96 & 98 & 108 & 108 & 9108 & 4857 \\
\hline $\mathrm{Ca}^{2+}$ & 1709 & 1694 & 194 & 216 & 2876 & 1662 \\
\hline $\mathrm{K}^{+}$ & 38159 & 38910 & 23048 & 22937 & 27794 & 16299 \\
\hline $\mathrm{Na}^{+}$ & 22855 & 28376 & 212795 & 214745 & 3503 & 1778 \\
\hline $\mathrm{S}_{\mathrm{tot}}^{2-}$ & 36191 & 36218 & 89500 & 91329 & $*$ & $*$ \\
\hline $\mathrm{Cl}^{-}$ & 204200 & 202100 & 201700 & 204200 & 667 & $*$ \\
\hline $\mathrm{Cu}^{2+}$ & 132 & 149 & 265 & 262 & 177 & 117 \\
\hline $\mathrm{Pb}^{2+}$ & 312250 & 298100 & 224250 & 247550 & 238 & 56 \\
\hline $\mathrm{Zn}^{2+}$ & 4110 & 4280 & 5085 & 4900 & 577 & 203 \\
\hline $\mathrm{Cd}^{2+}$ & 6363 & 6970 & 4625 & 4289 & 3 & $<0,8$ \\
\hline $\mathrm{Sb}^{3+}$ & 110 & 98 & 546 & 428 & $<16$ & $<16$ \\
\hline $\mathrm{Al}^{3+}$ & 248 & 256 & 251 & 209 & 129260 & 147875 \\
\hline $\mathrm{As}^{3-}$ & 300 & 248 & 1416 & 1348 & 71 & 122 \\
\hline $\mathrm{Si}^{2+}$ & 2086 & 2163 & 1462 & 1656 & 226180 & 247600 \\
\hline
\end{tabular}

Legend: *not analyzed elements

$\mathrm{S}_{\text {tot }}$ - total content of the element $\mathrm{S}$

A-fly ashes $(\mathrm{Pb}, \mathrm{K}, \mathrm{Cd}) \mathrm{X}$-ray differential analysis

B-fly ashes (Na, As, Sb) X -ray differential analysis

C-fly ashes analysed mass spectrometer [50]

D-fly ashes analysed mass spectrometer [51] 


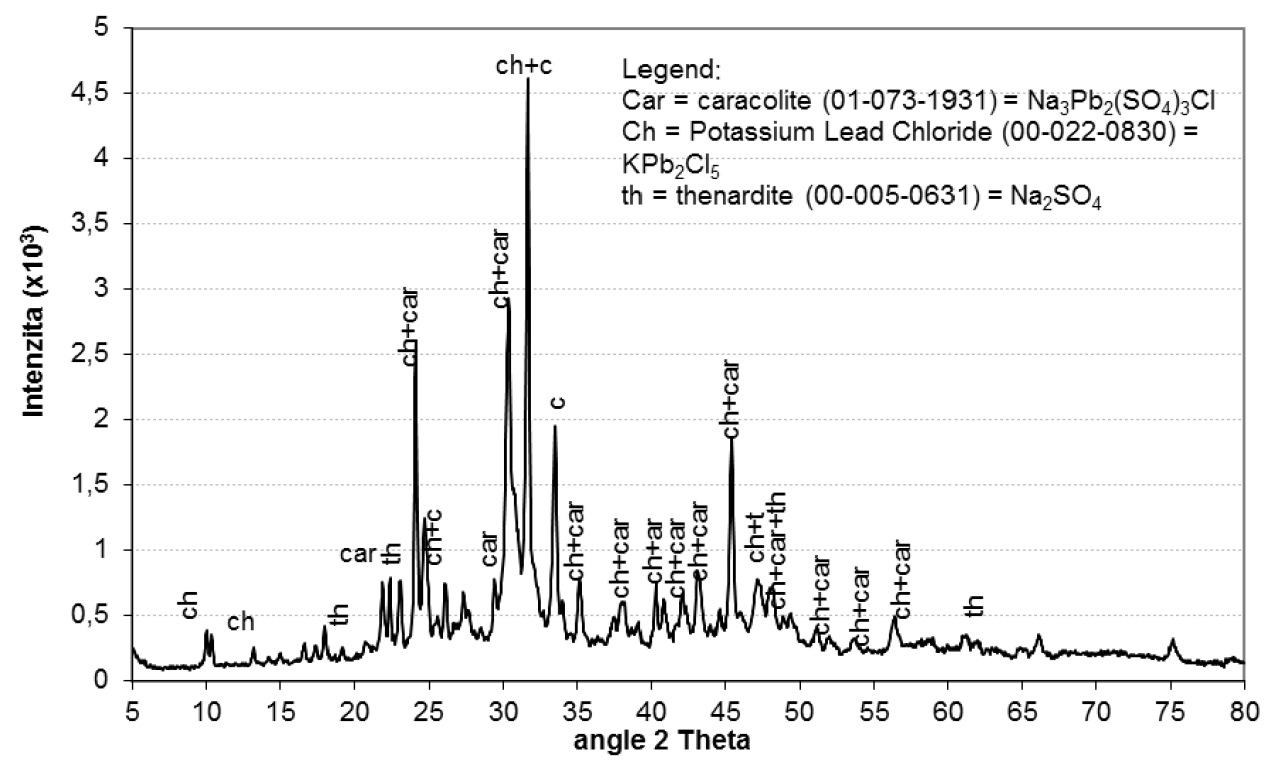

Fig. 1. Diffractogram of flyash sample B.

Furthermore, there is an important relative abundance of caracolite $\left(\mathrm{Na}_{3} \mathrm{~Pb}_{2}\left(\mathrm{SO}_{4}\right)_{3} \mathrm{Cl}\right)$ in residue $\mathrm{A}$ (Fig. 2).

The time-dependent infusion of the samples of fly ashes $\mathrm{A}$ and $\mathrm{B}$, when $\mathrm{L} / \mathrm{S}=10$ (the ratio between liquid and the solid phase), shows their different behavior (Figs 1-2). The test of fly ash A shows that the balance stabilization of metal infusion takes place within several hours. The release of $\mathrm{Pb}$ (up to the concentration of $1713 \mathrm{mg} / \mathrm{l}$ ) and Cd (up to the concentration of $889 \mathrm{mg} / \mathrm{l}$ ) is the most significant. Significantly lower concentrations in infusions have been found in $\mathrm{Zn}$ (up to $297 \mathrm{mg} / \mathrm{l}$ ) and $\mathrm{Cu}$ (do $8.7 \mathrm{mg} / \mathrm{l})$. Fly ash B presents a different behavior. Two different types of laboratory infusion tests of fly ash have also shown that the concentrations of especially $\mathrm{Cd}$ and $\mathrm{Zn}$ increase gradually and both elements show similar infusion graphs (Cd up to $329 \mathrm{mg} / \mathrm{l}$ and $\mathrm{Zn}$ up to $267 \mathrm{mg} / \mathrm{l}$ ). In comparison, $\mathrm{Pb}$ is infused slowly (than both metals and then in the case of sample A) and reaches the balance state after 48 hours (in comparison with A only up to $40 \mathrm{mg} / \mathrm{l})$. In comparison with fly ash $\mathrm{A}(\mathrm{pH} \sim 4.3)$, the $\mathrm{pH}$ in infusion $\mathrm{B}$ is higher and reaches the value of 6.3 .

Laboratory infusion tests of two different types of fly ash have also been performed. The solutions of all L/S tests showed a quick dissolution of the primary phases. Infusions with a high ratio of L/S can be used as a model for long-term leachability. It has been proven that the primary phases of especially caracolite $\left(\mathrm{Na}_{3} \mathrm{~Pb}_{2}\left(\mathrm{SO}_{4}\right)_{3} \mathrm{Cl}\right)$ and $\mathrm{KPb}_{2} \mathrm{Cl}_{5}$ were dissolved and the creation of stable anglesite $\left(\mathrm{Pb}_{2} \mathrm{SO}_{4}\right)$ took place (Fig. 3).

Within one year, 60-66\% of fly ash was dissolved. Especially caracolite $\left(\mathrm{Na}_{3} \mathrm{~Pb}_{2}\left(\mathrm{SO}_{4}\right)_{3} \mathrm{Cl}\right)$ and $\mathrm{KPb}_{2} \mathrm{Cl}_{5}$

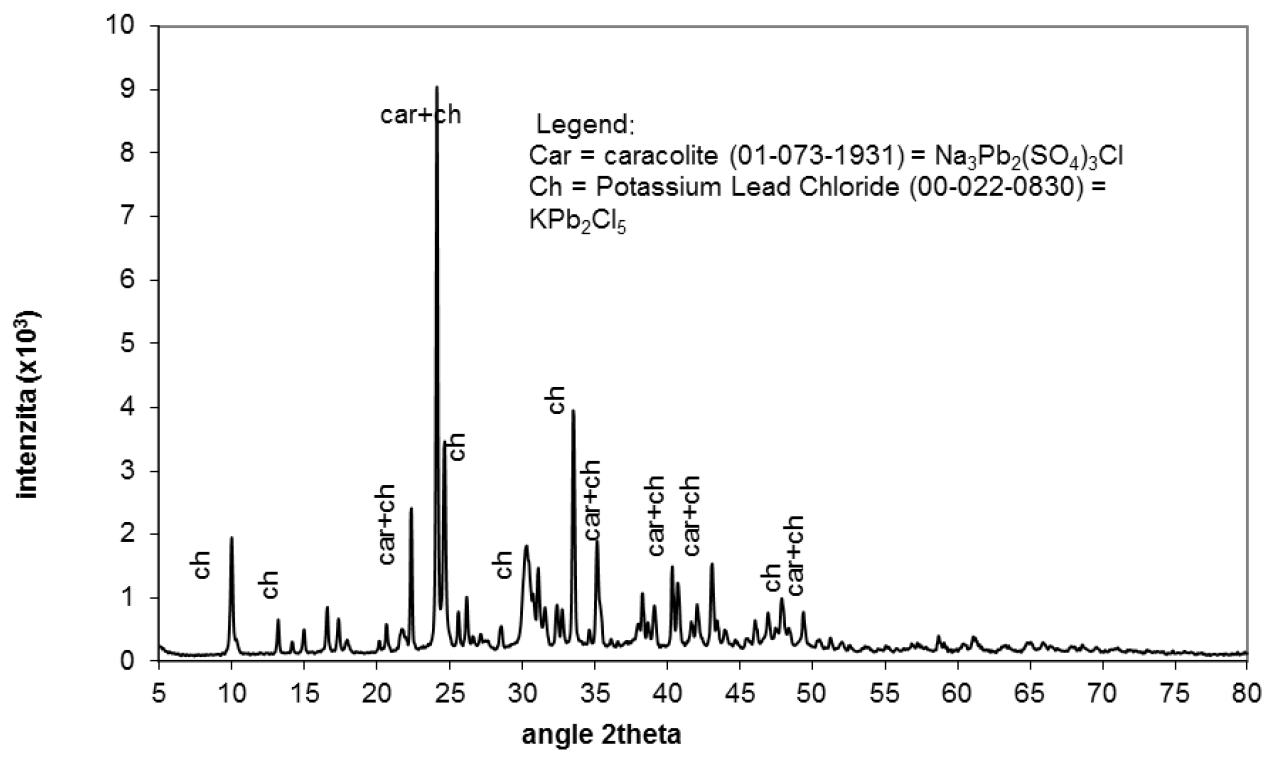

Fig. 2. Diffractogram of fly ash sample A. 


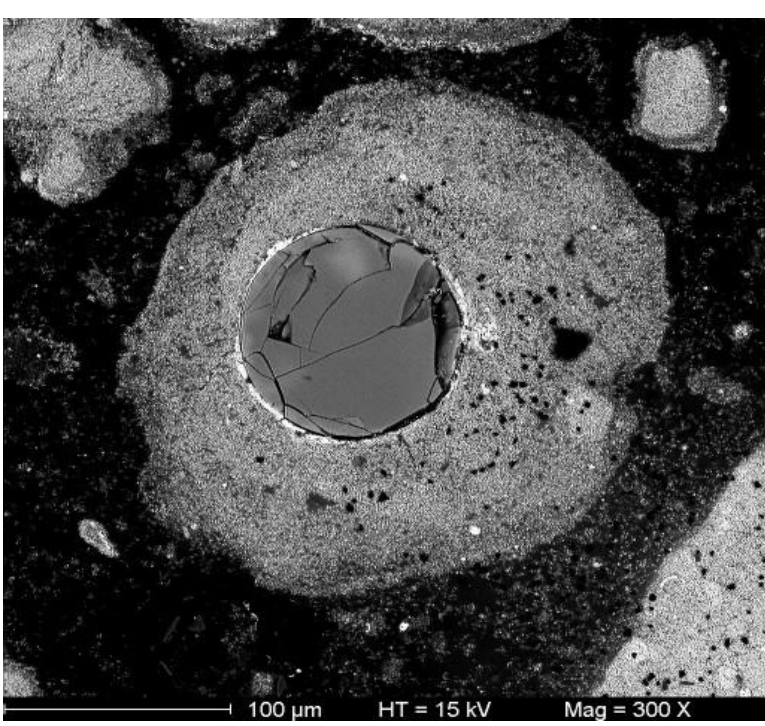

Fig. 3. Primary phase of caracolite $\left(\mathrm{Na}_{3} \mathrm{~Pb}_{2}\left(\mathrm{SO}_{4}\right)_{3} \mathrm{Cl}\right)$ and $\mathrm{KPb}_{2} \mathrm{Cl}_{5}$, with the formation of the secondary phase - anglesite $\left(\mathrm{PbSO}_{4}\right), \mathrm{PbSO}_{3}$ and the traces of carbonates

were dissolved, while creating secondary phases of anglesite $\left(\mathrm{PbSO}_{4}\right), \mathrm{PbSO}_{3}$ and traces of carbonates. The differences in results between the locations situated in woodlands and the locations in the open land are low. The major factor influencing lead infusion and its subsequent distribution into the soil profile is the $\mathrm{pH}$ value as opposed to $\mathrm{Cd}$ and $\mathrm{Zn}$, the infusion of which is nearly independent of $\mathrm{pH}$. A significant share of infused metals (mainly $\mathrm{Cd}$ and $\mathrm{Zn}$ ) was discovered in the labile soil fractions.

\section{Conclusions}

It is clear from the above-mentioned facts that the health protection of personnel, working in the observed environment, is very important in terms of the port logistics. As far as the environmental protection of the port in which the samples were collected, we can see that the testing of samples is not negligible. Simple standardized infusion tests (EN [50] and TCLP [51]) applied to the two types of samples occurring in the metallurgical industry represent high amounts of dissolution and phase transformation of ongoing processes and their solution by interaction. By the help of a set of 15 certified reference materials we carried out validation for determination of low concentrations of sulphur in geomaterials.

Through experiments it has been proven that the ICP OES method is suitable for determining the occurrence of sulphur in geomaterials with various contents of sulphur (including the concentration at the level of $\mathrm{mg} / \mathrm{kg}$ units). It has been confirmed that a suitable alternative to determining the volume of sulphur over $50 \mathrm{mg} / \mathrm{kg}$ in geomaterials is the combustion method with infrared detection.
Simultaneously, an analytic protocol for eliminating the influences of the matrix (especially for high contents of $\mathrm{Ca}$ and $\mathrm{Al}$ in the order of units up to tens of mass percentage) has been suggested. The main driving process was the condensation of cerusite, especially at $\mathrm{pH}>5$. Its concentration in infusion may be partially driven by the creation of anglesite or by adsorption on the surface of oxyhydroxides by the creation of iron. The thermodynamic simulation is carried out using the PHREEQC-2 computer code and shows that adsorption on the surface of iron oxyhydroxidesis commonly seen in newly created phases, and it is an effective apparatus for controlling the arsenic concentration in the leachate.

Wash-up tests in extreme conditions have shown that the presence of organic acids accelerates dissolution, and this is a cause of significant mobilization of metals.

Both types of fly ash from the metallurgy of $\mathrm{Pb}$ have been defined as dangerous waste; especially the concentrations of $\mathrm{Pb}, \mathrm{Cd}$, As and $\mathrm{Sb}$ exceeding the allowed limits significantly. However, the fly ash created in cooling combustion products using alkaline wastewater shows a higher stability from the environmental point of view. Contact with water initiated geochemical-mineralogical mechanisms of $\mathrm{Pb}$ detection. Especially the condensation of carbonates (cerusite $\mathrm{PbCO}_{3}$ and phosgenite $\mathrm{PbCl}_{2} \quad . \mathrm{PbCO}_{3}$ ) and secondary sulphates (anglesite $\mathrm{PbSO}_{4}$ ), which determine the concentration of $\mathrm{Pb}$ in infusion.

A possible technology for fly ash before eventual processing by melting in blast furnace has been suggested. It is based on the interaction of fly ash and alkaline water, equilibration with atmospheric $\mathrm{CO}_{2}$, spontaneous precipitation of $\mathrm{Pb} \mathrm{CO}_{3}$ and $\mathrm{Pb} \mathrm{SO}_{4}$, and the final use of the FERROX process for the purpose of precipitation of oxyhydroxides Fe(III) and adsorption of further contaminants from the solution. The main factor influencing the leaching of $\mathrm{Pb}$ from the studied fly ash and its subsequent distribution to the soil profile is $\mathrm{pH}$.

\section{Acknowledgements}

All authors contributed to this article equally with regard to the design, performing the experiments, data analysis and writing the paper.

\section{Conflict of Interest}

The authors declare no conflict of interest. No financial support from any funding sponsors has been received.

\section{References}

1. BADUlescu D., BUngaU C. BADUlescu A. Sustainable development through sustainable businesses. An empirical research among master students. Environmental Protection and Ecology, 16, 1101, 2015. 
2. BAZYOMO S.D.Y.B., LAWIN E. A., COULIBALY O., OUEDRAOGO. A. Forecasted Changes in West Africa Photovoltaic Energy Output by 2045. Climate, 4 (4), 2016.

3. KIFANYI G. E., NDAMBUKI J. M., ODA S. N. A Quantitative Groundwater Resource Management under Uncertainty Using a Retrospective Optimization Framework. Sustainability, 9 (1), 2017.

4. FAED A., CHANG E., SABERI M., HUSSAIN O.K., AZADEH A. Intelligent customer complaint handling utilizing principal component and data envelopment analysis. Applied Soft Computing, 47, 614, 2016.

5. LUNDORP K., JENSEN D.L., SORENSEN M.A., MOSBAEK H., CHRISTENSEN T.H. On-site treatment and landfilling of MSWI air pollution control residues. Hazaradous. Material, 97, 59, 2003.

6. WANG G.M., LUO Z.X., ZHANG J.Y., ZHAO Y. Modes of Occurrence of Fluorine by Extraction and SEM Method in a Coal-Fired Power Plant from Inner Mongolia, China. Minerals, 5 (4), 863, 2015.

7. GALON B., KORSCH M., BRADSHAW A. Impact of Dust from Ore Processing Facilities on Rain Water Collection Tanks in a Tropical Environment - The Obvious Source "Ain't Necessarily So". International Journal of Environment Res. Public Health, 13 (2), 243, 2016.

8. SAYAL A., AMJAD S., BILAL M., PERVEZ A., MAHMOOD Q., AFRIDI A. Industrial Water Contamination and Health Impacts: An Economic Perspective. Polish Journal of Environmental Studies, 25 (2), 765, 2016.

9. ODIGI M.I., UKREN L.O., NWANKWOALA H.O. Distribution of heavy metals in soils of Port Harcourt and its environs, Niger Delta, Nigeria. Chinese Journal Geochem., 30 (4), 415, 2011.

10. PALM C., NEILL C., LEFEBVRE P., TULLY K. Targeting Sustainable Intensification of Maize-Based Agriculture in East Africa. Tropical Conservation Sci. 10, 2017.

11. FISCHER C., GREAKER M., ROSENDAHL K.E. Robust technology policy against emission leakage: The case of upstream subsidies. Environmental Economics Management, 84, 44-61, 2017.

12. LAMSALI H. Selection of return channels and recovery options for used products. [Unpublished doctoral thesis], Loughborough University, Leicestershire, 2016.

13. ALUMUR S.A., NICKEL S., SALDANHA-DA-GAMA F., VERTER V. Multi-period reverse logistics network design, European. Operational Res., 220 (1), 67, 2012.

14. JOHNSON K., BROWN M. E. Environmental risk factors and child nutritional status and survival in a context of climate variability and change. Applied Geography, 54, 209-221, 2014.

15. BHATT K. The 2011 Guinean Mining Code: Reducing risks and promoting social benefit in Africa. South African J. Internat. Affairs, 20 (2), 247, 2013.

16. OKORO H.K., ORIMOLADE B.O., ADEBAYO G.B.B.A., XIMBA B.J., NGILA G.B. An Assessment of Heavy Metals Contents in the Soil around a Cement Factory in Ewekoro, Nigeria Using Pollution Indices. Polish Journal of Environmental Studies, 26 (1), 221, 2017.

17. ELHADDAD E., AL-ZYOUD S. The quality assessment of pollution of Rosetta branch, Nile River, Egypt. Arabian J. Geosci., 10 (5), 2017.

18. LIU F., CHEN W., YAN S., BAI B., JIANG D. Recovery Process of Decomposed Zirconium from Zirconium Metallurgical Slag.. Xiyou Jinshu. Chinese Journal Rare Metals, 41 (7), 831-836, 2017.
19. GÖKALP İ., UZ V. E., SALTAN M., TUTUMLUER, E. Technical and environmental evaluation of metallurgical slags as aggregate for sustainable pavement layer applications. Transportation Geotechnics, 14, 61-69, 2018.

20. AGALIT H., ZARI N., MAAROUFI M. Thermophysical and chemical characterization of induction furnace slags for high temperature thermal energy storage in solar power plants. Solar Energy, Materials Solar Cells, 172, 168, 2017.

21. STAKENIENE R., GALKUS A., JOKSAS K. Pollution of Klaipeda Port Waters. Polish Journal of Environmental Studies, 20 (2), 445, 2011.

22. POPESCU D.E., BUNGAU C., PRADA M., DOMUTA C., BUNGAU S. TIT D.M. Waste Management Strategy at a Public University in Smart City Context. J. Environ. Prot. Ecol., 17, 1011, 2016.

23. RADA E. C., CIOCA L.I. Optimizing the Methodology of Characterization of Municipal Solid Waste in EU under a Circular Economy Perspective. Energy Procedia, 119, 72, 2017.

24. PAWEŁCZYK A., BOZEK F., GRABAS K. Impact of military metallurgical plant wastes on the population's health risk. Chemosphere, 152, 513, 2016.

25. TSAI T.T., KAO C.M., SURAMPALLI R.Y.,WENG C.H., LIANG S.H. Treatment of TCE-Contaminated groundwater using fenton-like oxidation activated with basic oxygen furnace slag. J. Environ. Eng., 136 (3), 288, 2010.

26. BOZEK F., URBAN R. Management rizika. Obecná část. First ed; Publisher University of Defence in Brno, Czech Republic, 1, 145, 2008 [In Czech].

27. KITTEL CH. Introduction of Solid State Physics . Fifth ed; Publisher: Academia, Prague, Czech Republic, pp. 598, 1985 (translation from 1976) [In Czech].

28. LOVE C.T. Perspective on the Mechanical Interaction between Lithium Dendrites and Polymer Separatos at Low Temperature. J. Electrochem. Energy Conversion Stotage, 13 (3), 2016.

29. CARTER S., FISHER A.S., HINDS M.W., LANCASTER S., MARSHALL J., SHORE S. Atomic spectrometry update. Review of advances in the analysis of metals, chemicals and materials. J. Analytical Atomic Spectrom., 28 (12), 1814, 2013.

30. POTTS P.J. Geoanalysis: Past, present and future. In Proceedings Geoanalysis 97 - $3^{\text {rd }}$ International Conference on the Analysis of Geological and Environmental Materials, Australian Natl. Univ, Dept, Geol, Cambera, Australia. Jun 01-05, 1997.

31. NASKAR N., LAHIRI S., CHAUDHURI P. HF-free microwave assisted dissolution of soil samples for quantitative assessment of potassium. J. Indian Chem. Soc. 93 (7), 799, 2016.

32. HILL J. Inductively Coupled Plasma Spectrometry and its Applications. (2nd Edition). Blackwell Publishig, 427, 2008.

33. WELZ B., Sperling M. Atomic Absorption Spectrometry, ( $3^{\text {rd }}$ Edition), Weiley, NY, 964, 1999.

34. LOOS R., TAVAZZI S., MARIANI G. Analysis of emerging organic contaminants in water, fish and suspended particulate matter (SPM) in the Joint Danube Survey using solid-phase extraction followed by UHPLCMS-MS and GC-MS analysis. Sci.Total Environ., 607, 1201, 2017.

35. PATIL K.R., RANE V.P., SANGSHETTI J.N. A stability-indicating LC method for the simultaneous 
determination of telmisartan and ramipril in dosage form. Chromatographia, 67 (7-8), 575, 2008.

36. LAMBOURDIERE E. Globalization, service economy, and the Internet: New perspectives for regional development in the French Overseas Departments in South America and the Caribbean. Annales Geographie, 114 (645), 510, 2005.

37. HAVENGA J. H., DE BOD A., SIMPSON Z. P. A Logistics Barometer for South Africa: Towards sustainable freight mobility. J. Transport Supply Chain Manag., 10 (1), 2016.

38. BEYER C., KONRAD W., RÜGNER H., LIEDL R., GRATHWOHL P. Model-based prediction of long-term leaching of contaminants from secondary materials in road constructions and noise protection dams. Waste Management, 29 (2), 839, 2009.

39. WANG T., MÜLLER D.B., GRAEDEL T.E. Forging the anthropogenic iron cycle, Environ. Sci. Technology, 41 (14), 5120, 2007.

40. SOBANSKA S. Microchemical investigation of dust emitted by a lead smelter. Environ. Sci. Technology, 33, 1334, 1999.

41. OHMSEN G.S. Characterization of fugitive material within a primary lead smelter. Journal Air Waste Management, 51, 1443, 2001.

42. WAGMAN A. The NBS table of chemical thermodynamic properties: selected values for anorganic and $\mathrm{Cl}$ and $\mathrm{C} 2$ organic substance in SI units. Journal Physical Chemistry, $392,1982$.
43. DOYLE T.A., DAVIS A., RUNNELLS D.D. Predicting the Enviromental Stability of Treated Copper Smelter Flue Dust. Apply Geochemisty, 9, 337, 1994.

44. VANDECASTEELE C., DUTRE V., GEYSEN D., WAUTERS T. Solidification Stabilisation of Arsenic Bearning Fly Ash from the Metallurgical Industry Immobilisation Mechanism of Arsenic. Waste Management, 22, 143, 2002.

45. FIALA J. Qualitative and quantitative phase analysis. Bratislava, 1994.

46. KRAUS I., GANEV N. Diffraction analysis of mechanical stress. Publishing House CVUT, Prague, 1995.

47. KOCHANOVSKA A. The principles of phase quantitative analysis. In Material proceedings SVUMT. Prague, 1965.

48. ZEVIN L.S., KIMMEL G. Quantita-tive X-ray Diffractome-try, Springer-Verlag, New York, 1995.

49. VALVODA V., POLAROVA M., LUKAC P. Basics of structural analysis. Carolinum Prague, 1998.

50. EN 12457-2. Characterization of waste - leaching compliance test for leaching of granular waste materials and sludges. Part 2. One stage batch test at a liquid to solid ratio. Czech Standard Institute, Prague, 2002.

51. US EPA. Toxicity characteristic leaching procedure (TCLP), Method 1311. Solid Waste Characterization Manual SW-848. Test Methods for Evaluating Solid Waste. Physical/Chemical Methods, 1994. 